\title{
Factors affecting variations in exposure to infections by Leishmania donovani in eastern Sudan
}

D-E.A. Elnaiem, ${ }^{1}$ A.M. Mukhawi, ${ }^{1}$ M.M. Hassan, ${ }^{2}$ M.E. Osman, ${ }^{3}$ O.F. Osman, ${ }^{1}$ M.S. Abdeen ${ }^{4}$ and M.A. Abdel Raheem ${ }^{5}$

$$
\begin{aligned}
& \text { العوامل التي تؤثِّر على الاختلافات في التعرّض لعدوى الليشمانية الدونوفانية في شرق السودان }
\end{aligned}
$$

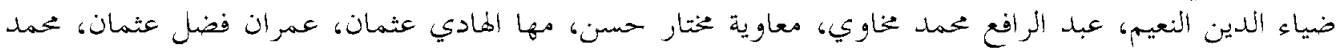

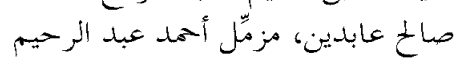

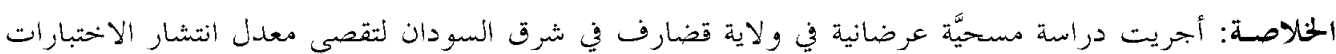

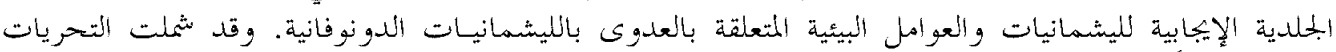

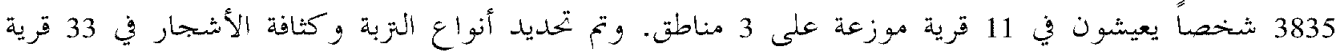

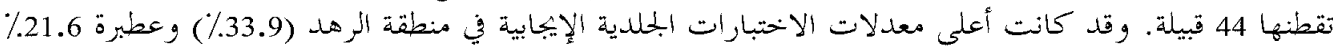

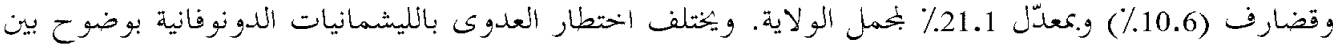

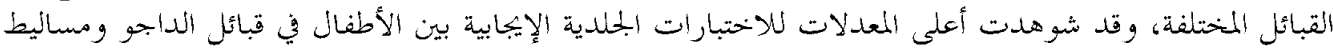

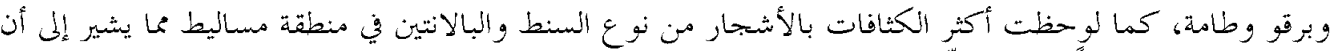

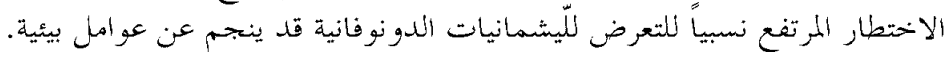

ABSTRACT A cross-sectional survey was carried out in Gedaref state, eastern Sudan to investigate the prevalence of positive leishmanin skin tests and environmental factors related to Leishmania donovani infection. A total of 3835 people living in 11 villages in 3 regions were screened. Soil types and tree densities were determined in 33 villages inhabited by 44 different tribes. The highest rates of positive skin tests were in Rahad region (33.9\%), Atbara (21.6\%) and Gedaref (10.6\%), with an average of $21.1 \%$ for the state. Risk of infection by $L$. donovani varied significantly between different tribes. Higher densities of Acacia and Balanites spp. trees were in Masaleet villages, suggesting that the relatively high risk of $L$. donovani exposure in this tribe is due to environmental factors.

Facteurs affectant les variations dans l'exposition aux infections par Leishmania donovani au Soudan oriental

RESUME Une étude transversale a été réalisée dans l'Etat de Gedaref au Soudan oriental pour déterminer la prévalence des intradermo-réactions positives à la leishmanine et les facteurs environnementaux liés à l'infection à Leishmania donovani. Au total, 3835 personnes vivant dans 11 villages dans 3 régions ont été examinées. Les types de sol et densités des arbres ont été déterminés dans 33 villages habités par 44 tribus différentes. Les taux les plus élevés d'intradermo-réactions positives se trouvaient dans la région de Rahad $(33,9 \%)$, Atbara $(21,6 \%)$ et Gedaref $(10,6 \%)$, avec une moyenne de $21,1 \%$ pour l'Etat. Le risque d'infection par $L$. donovani variait de façon significative entres les différentes tribus, les Dajo, Masalit, Bargo et Tama présentant les taux les plus élevés d'enfants positifs au test cutané. C'est chez les Masalit que l'on trouve de plus fortes densités d'arbres des espèces Acacia et Balanites, ce qui donne à penser que le risque relativement élevé de l'exposition à $L$. donovani est dû à des facteurs environnementaux.

${ }^{1}$ Department of Zoology, Faculty of Science, University of Khartoum, Khartoum, Sudan.

${ }^{2}$ Khartoum College of Medical Sciences, Aljerief West, Khartoum, Sudan.

${ }^{3}$ Commission for Biotechnology and Genetic Engineering, National Centre for Research, Ministry of

Science and Biotechnology, Khartoum, Sudan.

${ }^{4}$ Federal Ministry of Health, Khartoum, Sudan.

${ }^{5}$ Tabarakallah Hospital, Ministry of Health, Gedaref, Sudan.

المجلة الصحية لشرق المتوسط، منظمة الصحة العالمية، المجلد التاسع، العدد ع، بr..r. 


\section{Introduction}

Visceral leishmaniasis (VL), also known as kala-azar, is an important disease in Gedaref state, eastern Sudan [1-3] where its incidence has reached as high as 38 cases per 1000 person years [4]. In this region, VL is caused by 3 zymodemes of Leishmania donovani, classified as $L$. d. donovani, $L$. d. infantum and L. d. archibaldi [5]. The only vector is Phlebotomus (Larroussius) orientalis, which thrives in habitats characterized by Acacia seyal and Balanites aegyptica trees and black cotton soils [613]. Transmission of the disease takes place both in A. seyal and B. aegyptica woodland [10] and inside villages [12]. It is probable that both anthroponotic and zoonotic transmission of $L$. donovani take place in eastern Sudan. We have recently provided evidence that the Egyptian mongoose, Herpestes ichneumon, is a probable sylvatic reservoir host of $L$. donovani in woodland habitat [14]. Similarly, Dereure et al. [15] showed high infection rates of $L$. donovani in domestic dogs inside villages. In contrast, it is thought that the high incidence of post-kala-azar dermal leishmaniasis (PKDL) cases may present an accessible source of $L$. donovani for anthroponotic transmission [4,16,17].

Recent studies have shown marked differences in the incidence and in the ratios of clinical to sub-clinical infections of $L$. donovani in villages of Gedaref state, eastern Sudan, inhabited by different ethnic groups $[4,17]$ and provided evidence for the genetic basis for susceptibility to VL $[18,19]$. However, little is known about ethnic variations in exposure to $L$. donovani infection and their relationship to environmental factors [19].

Despite an expansion in knowledge about the epidemiology of VL in eastern Sudan, few studies have attempted to clas- sify the endemicity of the disease and determine the risks of $L$. donovani infections in different places and populations of Gedaref state [17]. Using a geographical information systems (GIS) approach, we have recently developed environmental based risk maps for the incidence of VL in Gedaref state [20]. We found that, within this region, rainfall and altitude are the best predictors of incidence of VL. The models showed that the predicted incidence of VL in Gedaref state starts from zero in the northern and central parts of the state, gradually increasing to its maximum towards the Atbara and Rahad rivers.

In this paper, we present results of a cross-sectional survey to study exposure to infection by L donovani in different regions and by different populations in eastern Sudan. We also investigated the effects of vegetation on variations in exposure to $L$. donovani infections among different tribes.

\section{Methods}

\section{Study area and population}

The field survey described in this study was carried out during March-April 2001 in 33 villages located in 3 regions ('mahalayias') in Gedaref state, eastern Sudan: Rahad, Gedaref and Atbara (Figure 1). These regions were previously shown to have different levels of VL endemicity [20]. Detailed descriptions and maps of the study area were given in a previous publication [20]. According to the most recent estimates, Gedaref state has a total population of 1137642 people. Most of the land is covered by black cotton soils, with few scattered sandy places, known locally as 'azaza' soils. The climate of the area is tropical continental with an estimated annual rainfall between 400 and $1400 \mathrm{~mm}$.

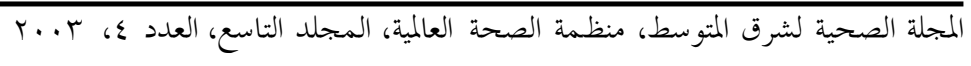




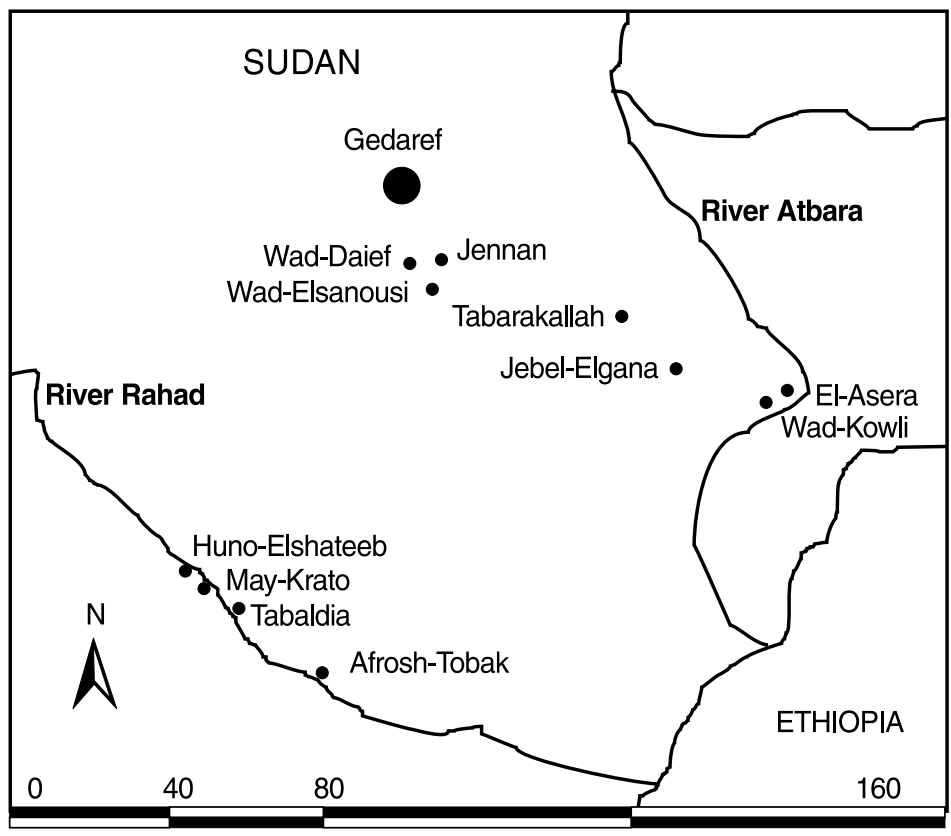

Figure 1 Map of Gedaref state showing location of the 11 study villages surveyed for history of exposure to infection by Leishmania donovani

The year is sharply divided between a rainy season (June-October) and a dry season (November-May). Dry savannah woodland is the natural vegetation of Gedaref state. B. aegyptica (known locally as ' $h i g$ leeg'), A. seyal ('taleh'), A. senegal ('hashab'), A. mellifera ('kiter') and Combretum spp. are the most abundant indigenous trees.

\section{Ethical considerations}

Before the field surveys, the protocol of the study was ethically approved by the Research Board of the Faculty of Science, University of Khartoum. Informed consent was obtained form each participant. For children, the consent was obtained from their parents.

\section{Field surveys}

We measured the geographical variation in exposure to $L$. donovani infections by determining the frequency of the population who were positive for the leishmanin skin test in the 3 regions, which previously showed different levels of VL endemicity [20]. In general, a positive test result is known to indicate a previous exposure to Leishmania infection. Since no other Leishmania spp. parasites are known to circulate in the study area, we considered that all positive test results to be $L$. donovani infection.

Leishmanin skin test screening was carried out in 11 villages: 4 close to the Atbara river (Wad-Kowli, Jebel-Elgana, El-Asera and Tabarakallah), 3 close to Gedaref town

المجلة الصحية لشرق المتوسط، منظمة الصحة العالمية، المجلد التاسع، العدد ع، ب... 
(Jennan, Wad-Elsanousi and Wad-Daief) and 4 close to the Rahad river (May-Krato, Tabaldia, Afrosh-Tabak and Huno-El shateeb).

In each village, the research team explained the objectives of the study and asked for the whole population to participate in an interview and medical examination, to determine their ethnic group, age, sex, history of settlement, history of VL and leishmanin skin test status. Particular attention was paid to the age of subjects and history of settlement in the area. In addition to people refusing to participate in the study, we also excluded those who were not lifelong residents of the villages or had no accurate age records.
Following the interview, each subject was examined by a medical doctor and a medical assistant for scars of cutaneous leishmaniasis and signs of active VL, malaria and other illnesses. A leishmanin skin test was conducted as described by Ziljstra et al. [4] and Khalil et al. [17]. Briefly, 0.1 $\mathrm{mL}$ of leishmanin antigen (L. infantum, donated by the Istituto Superiore di Sanita, Rome) was injected intradermally to the volar aspect of the left arm. The result of the test was read 48 hours after injection and induration sizes $\geq 5 \mathrm{~mm}$ were considered positive.

Following leishmanin screening, we conducted an ecological survey to record the type of soil and density of vegetation in

Table 1 Distribution of tribes in the populations studied for exposure to infection by Leishmania donovani in Gedaref state, eastern Sudan

\begin{tabular}{|c|c|c|c|c|c|c|c|c|}
\hline Tribe & \multicolumn{2}{|c|}{$\begin{array}{c}\text { Rahad region } \\
\% \text { of } \\
\text { No. region }\end{array}$} & \multicolumn{2}{|c|}{$\begin{array}{c}\text { Gedaref region } \\
\% \text { of } \\
\text { No. } \quad \text { region }\end{array}$} & \multicolumn{2}{|c|}{$\begin{array}{c}\text { Atbara region } \\
\% \text { of }\end{array}$} & \multicolumn{2}{|c|}{$\begin{array}{c}\text { Total Gedaref state } \\
\% \text { of }\end{array}$} \\
\hline Bargo & 68 & 5.7 & 38 & 2.2 & 141 & 7.4 & 247 & 5.1 \\
\hline Bederia & 0 & 0 & 559 & 31.8 & 0 & 0 & 559 & 12.0 \\
\hline Benamer & 0 & 0 & 0 & 0 & 157 & 8.2 & 157 & 3.2 \\
\hline Benhelba & 0 & 0 & 0 & 0 & 54 & 2.8 & 54 & 1.1 \\
\hline Benrashid & 171 & 14.5 & 3 & 0.2 & 107 & 5.6 & 281 & 5.8 \\
\hline Dajo & 86 & 7.3 & 3 & 0.2 & 48 & 2.5 & 137 & 2.8 \\
\hline Fallata & 108 & 9.1 & 0 & 0 & 18 & 0.9 & 126 & 2.6 \\
\hline Gemir & 0 & 0 & 1 & 0.1 & 210 & 11.0 & 211 & 4.4 \\
\hline Housa & 543 & 45.9 & 3 & 0.2 & 0 & 0 & 546 & 11.0 \\
\hline Marareet & 7 & 0.6 & 506 & 28.8 & 3 & 0.2 & 516 & 11.0 \\
\hline Masaleet & 118 & 10.0 & 35 & 2.0 & 496 & 26.0 & 649 & 13.0 \\
\hline Meseiria & 29 & 2.5 & 4 & 0.2 & 239 & 13.0 & 272 & 5.6 \\
\hline Rezigat & 0 & 0 & 0 & 0 & 100 & 5.2 & 100 & 2.1 \\
\hline Tama & 32 & 2.7 & 383 & 21.8 & 32 & 1.7 & 447 & 9.2 \\
\hline Other & 21 & 1.7 & 221 & 12.5 & 306 & 15.5 & 548 & 11.1 \\
\hline Total & 1183 & 100.0 & 1756 & 100.0 & 1911 & 100.0 & 4850 & 100.0 \\
\hline
\end{tabular}

المجلة الصحية لشرق المتوسط، منظمة الصحة العالمية، المجلد التاسع، العدد ع، بr. 
the study villages. In each village, the research team counted the number of trees of different species found in a total area of 80 000-100 000 square metres, divided into 80-100 quadrates, each measuring $1000 \mathrm{~m}^{2}$. The soil type was recorded as black cotton soil, sandy soil, rocky and gravel soil or a mixture of sandy and clay soil ('azaza'). In addition to the 11 villages mentioned above, the ecological survey was extended to include an additional 22 villages inhabited by different tribes.

The data from the medical and ecological surveys were entered and analysed with SPSS version 10 software. The participants were classified as children ( $\leq 16$ years old) and adults ( $>16$ years old). The proportion of leishmanin positive people in different regions and different tribes were compared using the chi-squared test. The data of the vegetation in each village was summarized as tree density per $10000 \mathrm{~m}^{2}$. Following log transformations, comparisons were made between village densities of Acacia, Balanites and Azadirachta indica (neem) trees, using Student $t$-test.

\section{Results}

The epidemiological survey carried out in the present study covered 11 villages with a total population of 32535 people living in different habitats in the area. Out of the total population of the villages, 4850 people (2800 females and 2050 males) were confirmed as lifelong residents of the villages and were included in the analysis of the ethnic structure of the endemic area.

The survey population belonged to 44 different tribes, dominated by the Masaleet, Bederia, Housa, Marareet and Tama (Table 1). The frequency of people belonging to each tribe varied in different regions. In the Rahad river region, the Housa were the largest group (45.9\%), whereas in Gedaref region, the main tribes of the study population were Bederia (31.8\%), Marareet (28.8\%) and Tama (21.8\%). In Atbara, the study population belonged mainly to the Masaleet (26\%).

A total of 3835 people had accurate age records and were included in the skin test study of exposure to $L$. donovani infection: 1461 in villages of the Atbara region, 1338 in Gedaref and 1036 in Rahad. The average positive skin test rate in all Gedaref state was $21.1 \%$ (13.5\% in children, $40.5 \%$ in adults). There was a significant difference in the proportion of leishmanin-positive people found in the 3 study regions $(P<$ 0.001 , Figure 2). The highest positive rate was encountered in Rahad region (33.9\%) followed by Atbara (21.6\%) and Gedaref (10.6\%).

Due to differences in the sample size taken from different age groups, we restricted the tribal comparisons of skin tests to the 2299 children only ( $\leq 16$ years) (Table 2). We found significant differences in the exposure of different tribes in the high

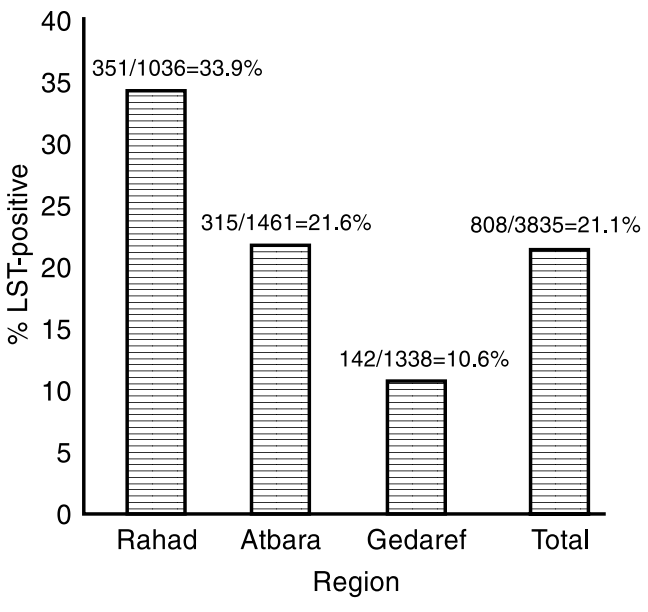

Figure 2 Proportions of subjects positive for the leishmanin skin test (LST) in 3 regions of Gedaref state

المجلة الصحية لشرق المتوسط، منظمة الصحة العالمية، المجلد التاسع، العدد ع، ب...T 


\begin{tabular}{|c|c|c|c|c|c|c|}
\hline \multirow[t]{2}{*}{ Tribe } & \multicolumn{2}{|c|}{ Rahad region } & \multicolumn{2}{|c|}{ Atbara region } & \multicolumn{2}{|c|}{ Gedaref region } \\
\hline & No. tested & $\%$ positive & No. tested & $\%$ positive & No. tested & $\%$ positive \\
\hline Dajo & 67 & 50.8 & - & - & - & - \\
\hline Masaleet & 92 & 38.0 & 340 & 20.0 & - & - \\
\hline Benrashid & 115 & 25.2 & - & - & - & - \\
\hline Fallata & 73 & 15.1 & - & - & - & - \\
\hline Housa & 324 & 11.4 & - & - & - & - \\
\hline Gemir & - & - & 103 & 18.5 & - & - \\
\hline Benamer & - & - & 89 & 18.0 & - & - \\
\hline Bargo & - & - & 81 & 17.3 & - & - \\
\hline Meseiria & - & - & 139 & 7.9 & - & - \\
\hline Rezigat & - & - & 60 & 6.7 & - & - \\
\hline Bederia & - & - & - & - & 286 & 4.9 \\
\hline Marareet & - & - & - & - & 282 & 3.9 \\
\hline Tama & - & - & - & - & 248 & 2.8 \\
\hline \multirow[t]{2}{*}{ Total } & 671 & 21.8 & 812 & 16.3 & 816 & 3.9 \\
\hline & \multicolumn{2}{|c|}{$\chi^{2}=21.13, P=0.001$} & \multicolumn{2}{|c|}{$\chi^{2}=15.28, P=0.009$} & \multicolumn{2}{|c|}{$\chi^{2}=1.52, P=0.47$} \\
\hline
\end{tabular}

Dashes indicate that no tribe members were found in the sample from that region.

transmission regions of the Rahad and Atbara rivers $(P<0.001$ and $P=0.009$ respectively), but not in Gedaref region $(P=$ 0.469). In Rahad, the highest LST positive rates were observed in the Dajo tribe (50.8\%), followed by the Masaleet (38.0\%), Benrashid (25.2\%), Fallata (15.1\%) and Housa (11.4\%). In Atbara region, the highest LST positive rates were observed in the Masaleet (20.0\%), Gemir (18.5\%), Benamer (18.0\%) and Bargo $(17.3 \%)$ tribes. Lowest rates were observed in the Meseiria (7.9\%) and Rezigat (6.7\%).

During the survey, we noticed a large difference in the ecology of the villages inhabited by Masaleet and other tribes in Gedaref state. However, because of the small number of villages inhabited by some tribes, we restricted our statistical analysis to Masaleet and Housa-Fallata villages (11 and 6 villages, respectively). The average densities (per $10000 \mathrm{~m}^{2}$ ) of Acacia and Balanites spp. trees and Az. indica trees found in these villages showed that villages of the Masaleet people have significantly higher $(P=0.005)$ densities of Acacia and Balanites spp. trees (mean \pm standard error $58.0 \pm 7.2$ trees) than the villages of the Housa and the Fallata people $(17.0 \pm 6.5$ trees) (Figure 3). In contrast, we observed higher densities of $A z$. indica trees in the Housa-Fallata villages $(48.0 \pm 27.6$ trees) than in the Masaleet villages $(10.9 \pm 2.4$ trees), although this difference was not statistically significant $(P=0.090)$. Interest- 


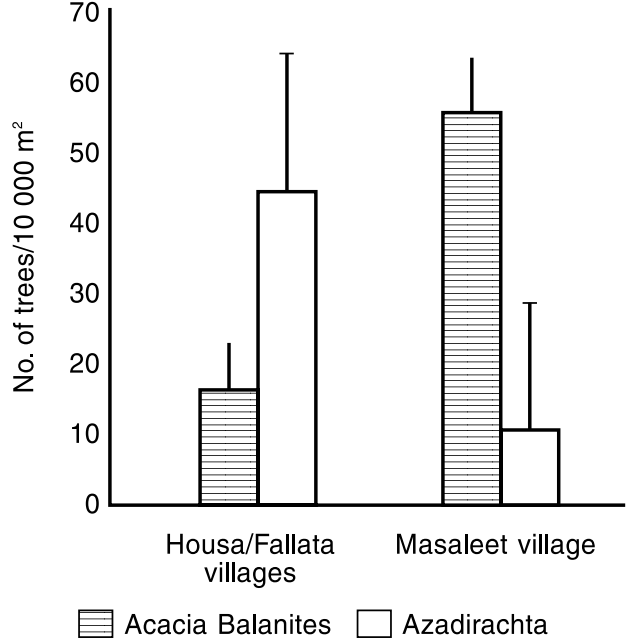

Figure 3 Densities of natural vegetation (Acacia and Balanites spp.) and recently introduced Azadirachta indiaca trees in villages of Housa/Fallata and Masaleet tribes in Gedaref state

ingly, the densities of $B$. aegyptica trees in the Masaleet villages were significantly higher than the densities of the Az. indica trees $(P=0.007)$, whereas the two types of vegetation showed similar densities in the Housa-Fallata villages $(P=0.276)$.

We also observed that there were more Masaleet villages on black cotton soils than Housa-Fallata villages, which were located on sandy ('azaza') soils. Six out of the 11 Masaleet villages were on pure black cotton soils and the other 5 were on mixed black cotton soils with a few scattered sandy sites. In contrast, all Housa-Fallata villages were on sandy soil.

\section{Discussion}

Appropriate health planning and control of vector-borne diseases depends on proper understanding of times and places of pathogen transmission and which communities are at more risk of contracting the infection. In this study, we used leishmanin skin testing to study the endemicity of VL in one state of Sudan and to determine whether different tribes have similar rates of exposure to infection by the parasite. We also investigated the ecology of villages inhabited by different tribes and described their vegetation and soil characteristics.

Leishmanin skin testing is known to give a reliable indication of previous exposure to infection by Leishmania spp. parasites. Exposed people usually develop a lifelong positive skin test reaction [4]. In Gedaref state, a positive test implies exposure to $L$. donovani only, since no other Leishmania spp. parasites are known to circulate in the area.

We found that the average rate of skin test positive cases in Gedaref state is $21.1 \%$ with significant variation between different regions. The highest rate was in Rahad region (33.9\%) followed by Atbara (21.6\%) and Gedaref (10.6\%). These results conform to the general pattern of endemicity obtained in the previously described GIS models [20]. Based on the two studies, we suggest that Gedaref state has two main VL endemic zones: a low endemicity zone in the central region (around Gedaref city) and a high endemicity zone around the Rahad and Atbara rivers.

Our results showed that in the Rahad region, the Masaleet, Dajo and Benrashid tribes are at higher risk of exposure to $L$. donovani infections than the Housa and Fallata tribes. Similarly, in the Atbara region, the Masaleet, Bargo, Gemir and Benamer were at higher risks of infection than the Meseiria and Rezigat tribes. These results support previous work reporting higher skin-test positive rates in a Masaleet village (Umsalala) than a Housa village (Mushra’a Kuka) [17].

المجلة الصحية لشرق المتوسط، منظمة الصحة العالمية، المجلد التاسع، العدد ع، ب... 
Since no evidence exists on genetic differences in attraction to phlebotomine sand flies, the observed tribal variation in exposure to $L$. donovani infections can be explained by two possible hypotheses. First, these differences could be due to environmental factors, indicating that the Masaleet people live in places with higher transmission intensities than the Housa and Fallata people. Our ecological observations support this hypothesis, since we noticed that the villages of the Masaleet and Bargo people have denser vegetation of Balanites and Acacia trees than those of the Housa and the Fallata. We also observed that in most Housa and Fallata villages, the natural vegetation has been replaced by Az. indica (neem) trees. This tree is planted to provide shade and there is mounting evidence that it has some repellent effects against $P$. orientalis [21, unpublished report by $\mathrm{J}$. Schorscher, MSF-Holland]. Furthermore, the Masaleet villages were mostly located on black cotton soil, whereas those of the Housa and the Fallata were located on sandy soils. It is known that the presence of $P$. orientalis, the vector of $L$. donovani in the region, is highly associated with black cotton soils $[10,13]$.

The second hypothesis for the ethnic variation in exposure to infective bites of sand flies is that certain social habits predispose people to infection. For example, children and susceptible adults of certain tribes may spend more night-time hours outdoors, where most of the biting activity of $P$. orientalis takes place [8].

The environmental differences between the Housa-Fallata and the Masaleet villages may be related the history of settlement and other socioeconomic factors. The settlement of the Fallata and the Housa people took place several decades earlier than the Masaleet and therefore they may have a better opportunity of choosing and chang- ing the habitat in their villages. However, this explanation does not exclude the possibility that the habitats in a Masaleet village were chosen and intentionally maintained to serve their way of life. During our work in eastern Sudan, we noticed that in comparison with other tribes, the Masaleet people are more dependent on the local environment for food and may therefore need to live close to dense vegetation. In contrast, the Housa and the Fallata people are more dependent on agriculture and livestock.

Because of time and logistic limitations, our study did not address the questions of incidence of VL and ratios of clinical/subclinical disease, which have been investigated thoroughly in previous work $[4,17]$. These studies showed significant differences between two villages in ratios of clinical to sub-clinical $L$. donovani infections and suggested that, although genetic factors are not excluded, these differences may be mainly due to variations in exposure to the parasite. We suggest that future studies should address the socioeconomic dimensions of exposure to $L$. donovani infection. Lessons from tribal habits that reduce their exposure to $L$. donovani infections should be an integral part of any health education scheme and may provide the basis for a sustainable control programme.

\section{Acknowledgements}

We would like to thank Khartoum Office of MSF-Holland and the Ministry of Health of Gedaref State for help and support. We are grateful to the extended support from Dr Marina Gramiccia (Istituto Superiore di Sanita), who donated 5000 doses of leishmanin antigen. In the field, we received much help from the Ministry of Health and the teachers of the primary schools in the

المجلة الصحية لشرق المتوسط، منظمة الصحة العالمية، المجلد التاسع، العدد ع، ب... 
endemic villages, who participated in the tree count of the villages. Thanks are due to Dr Fathi M. Elraba’a, Dr M. A. Kambal, Dr S. Abukashawa (Faculty of Science, University of Khartoum), Prof. A. M. El Hassan (Institute of Endemic Diseases, University of Khartoum), Dr Ibrahim M. El Hassan (IED) and Dr Hayder Giha (Department of Biochemistry, University of Khartoum) for their help and support.
This investigation received technical and financial support from the joint WHO Eastern Mediterranean Region (EMRO), Division of Communicable Diseases (DCD) and the WHO Special Programme for Research and Training in Tropical Diseases (TDR): the EMRO/DCD/TDR Small Grants Scheme for Operational Research in Tropical and Communicable Diseases.

\section{References}

1. Desjeux P. Information on the epidemiology and control of the leishmaniases by country and territory. Geneva, World Health Organization, 1991 (WHO/ LEISH/91.30).

2. Desjeux P. Leishmaniasis. Public health aspects and control. Clinics in dermatology, 1996, 14:417-23.

3. El-Hassan AM et al. Recent observations on the epidemiology of kala-azar in the eastern and central states of the Sudan. Tropical and geographical medicine, 1995, 47:151-6.

4. Zijlstra EE et al. Endemic kala-azar in eastern Sudan: a longitudinal study on the incidence of clinical and subclinical disease and post-kala-azar-dermal leishmaniasis. American journal of tropical medicine and hygiene, 1994, 51: 826-36.

5. Oskam L et al. Biochemical and molecular characterization of leishmania parasites isolated from an endemic focus in eastern Sudan. Transactions of the Royal Society of Tropical Medicine and Hygiene, 1998, 92:120-2.

6. Quate LW. Phlebotomus sandflies of the Paloich area in the Sudan (Diptera, Psychodidae). Journal of medical entomology, 1964, 1:213-68.

7. Hoogstraal H, Heynemann D. Leishmaniasis in the Sudan Republic. 30. Final epidemiological report. American journal of tropical medicine and hygiene, 1969, 18:1091-210.

8. Elnaiem DA, Hassan HK, Ward RD. Phlebotomine sandflies in a focus of visceral leishmaniasis in a border area of eastern Sudan. Annals of tropical medicine and parasitology, 1997, 91:307-18.

9. Elnaiem DA et al. Infection rates of Leishmania donovani in Phlebotomus orientalis. Annals of tropical medicine and parasitology, 1998, 92:229-32.

10. Elnaiem DA et al. Environmental determinants of the distribution of Phlebotomus orientalis in Sudan. Annals of tropical medicine and parasitology, 1998, 92:877-87.

11. Elnaiem DA, Hassan HK, Ward RD. Association of Phlebotomus orientalis and other sandflies with vegetation types in the eastern Sudan focus of kala-azar. Medical and veterinary entomology, 1999, 13:198-203.

12. Elnaiem DA, Osman OF. Evidence for active transmission of visceral leishmaniais within a village in eastern Sudan. Acta tropica, 1998, 71:305-9.

13. Thomson $M$ et al. Towards a kala-azar risk map for Sudan. Mapping the potential distribution of Phlebotomus orientalis using digital data of environmental

المجلة الصحية لشرق المتوسط، منظمة الصحة العالمية، المجلد التاسع، العدد ع، r...ب 
variables. Tropical medicine and international health, 1999, 4:105-13.

14. Elnaiem DA et al. The Egyptian mongoose, Herpestes ichneumon, is a possible reservoir host of visceral leishmaniasis in eastern Sudan. Parasitology, 2001, 122:531-6.

15. Dereure $\mathrm{J}$ et al. Visceral leishmaniaisis in Sudan: first identification of Leishmania from dogs. Transactions of the Royal Society of Tropical Medicine and Hygiene, 2000, 94:154-5.

16. Zijlstra EE et al. Post kala-azar dermal leishmaniasis in the Sudan: clinical presentation and differential diagnosis. British journal of dermatology, 2000, 142: 1-9.

17. Khalil EA et al. Epidemiology and clinical manifestations of Leishmania donovani infection in two villages in an endemic area in eastern Sudan. Tropical medicine and international health, 2002, 7:35-44.
18. Mohamed HS et al. Genetic susceptibility to visceral leishmaniasis in the Sudan: linkage and association with IL4 and IFNGR1. Genes and immunity, 2003, 4, 351-5.

19. Bucheton B et al. The interplay between environmental and host factors during an outbreak of visceral leishmaniasis in eastern Sudan. Microbes and infection, 2002, 4:1449-57.

20. Elnaiem DA et al. Risk mapping of visceral leishmaniasis: the role of local variations in rainfall and altitude on the presence and incidence of kala-azar in eastern Sudan. American journal of tropical medicine and hygiene, 2003, 68:10-7.

21. Mulla MS, Su T. Activity and biological effects of neem products against arthropods of medical importance. Journal of the American Mosquito Control Association, 1999, 15:133-52.

\section{Current control strategy for leishmaniasis}

The main control strategy is case finding and treatment plus, when feasible, vector control and, in zoonotic foci, animal reservoir control. For visceral leishmaniasis, serological diagnosis is based on the enzyme linked immunosorbent assay, indirect fluorescent antibody test and the direct agglutination test, while parasitological diagnosis relies on spleen, bone marrow or lymph node aspirates. For treatment, first-line drugs are the pentavalent antimonials (Sb5+), and second-line drugs are amphotericin B and Ambisome (amphotericin B in liposomes), the latter in industrialized countries only due to the high cost. For cutaneous leishmaniasis, parasitological diagnosis is based on skin smears and treatment on pentavalent antimonials.

Vector control, in the case of peri-domestic and intra-domiciliary transmission, relies on spraying of houses with residual insecticide (usually pyrethroids). Sandflies are still very sensitive to insecticides. Animal reservoir control for visceral leishmaniasis is based, in developing countries, on culling seropositive dogs, and for cutaneous leishmaniasis, is based on the use of poison baits and environmental management to control rodents.

Source: http://www.who.int/tdr/diseases/leish/direction.htm

$$
\text { المجلة الصحية لشرق المتوسط، منظمة الصحة العالمية، المجلد التاسع، العدد ؟، ب... }
$$

